\title{
Use of Soil Enzymes as Indicators for Contaminated Soil Monitoring and Sustainable Management
}

\author{
Sang-Hwan Lee ${ }^{1, *}$, Min-Suk Kim ${ }^{2} \mathbb{D}$, Jeong-Gyu Kim ${ }^{2} \mathbb{D}$ and Soon-Oh Kim ${ }^{3}$ \\ 1 Technical Research Institute, Mine Reclamation Corporation, Wonju 26464, Korea \\ 2 O-Jeong Resilience Institute, Korea University, Seoul 02841, Korea; adoniss86@korea.ac.kr (M.-S.K.); \\ lemonkim@korea.ac.kr (J.-G.K) \\ 3 Department of Geology and Research Institute of Natural Science (RINS), Gyeongsang National University, \\ Jinju 52828, Korea; sokim@gnu.ac.kr \\ * Correspondence: soillsf@mireco.or.kr; Tel.: 82-33-902-6740
}

Received: 9 September 2020; Accepted: 4 October 2020; Published: 5 October 2020

check for updates

\begin{abstract}
Diagnosis of the risk of soil pollution and the performance of measures for the recovery of contaminated soil requires proper monitoring of the extent of soil function damage and its recovery process. Soil enzymes reveal ecosystem perturbations, are sensitive to management choices, and have been used as indicators of biogeochemical cycles, organic matter degradation, and soil remediation processes. Thus, enzymes can indicate, along with other physical or chemical properties, soil quality. In this paper, we review the effects of soil pollutants [toxic trace elements (TTE), and petroleum hydrocarbons (PHC)] on enzymatic activities and evaluate the usefulness of soil enzyme's activity for monitoring recovery processes in contaminated soil. Soil enzymes can be said to be a powerful means of monitoring to properly indicate the degree of deterioration of soil quality caused by soil pollution and to diagnose the process of functional recovery of contaminated soil. Further research is needed to establish the quantitative relationships between the soil physico-chemical properties and enzyme activity and the effect of soil remediation on the functional recovery of soil-related to soil quality.
\end{abstract}

Keywords: monitoring indicators; soil contamination; soil enzyme; soil quality; sustainable remediation

\section{Introduction}

The problem of soil pollution, which is contaminated and impaired by various human activities such as industrial activity and waste speculation, is a global problem [1]. Soil is a natural environment consisting of a mixture of organic and inorganic components present in the gaseous, aqueous, and solid states. Soils differ significantly in their genetic and environmental characteristics but generally function as reservoirs of water and nutrients that support the plant growth and microorganisms [2].

Soil quality can be defined as the ability to maintain soil-specific functions properly and is related to the productivity and sustainability of soil, such as the growth medium of various plants and organisms, the maintenance of air and water quality, the buffering of events such as various pollution, and act as a self-remediating system [3,4].

The diagnosis of soil quality can be conducted by using appropriate indicators to compare with changes over time, i.e., pre-disturbance conditions, which should be able to respond sensitively to changes. Soil health means the proper balance between organisms and the surrounding environment within the soil ecosystem. Any disturbance to the soil due to the detrimental effects of pollutants on soil biochemical activities affects soil health, affecting soil functions. Irreversible changes in soil function due to pollutants' inputs are accompanied by a degrade soil quality, a decrease in productivity, and negative consequences for the overall environment. When the environment is qualitatively or quantitatively characterized by pollution, the evaluation of pollution levels, as well as the soil structure, 
function, and composition of the soil system, are essential to ensure changes in soil quality through the restoration process [5].

In most countries where soil environment management programs are introduced, approaches to reducing risk to acceptable levels for humans and the environment are adopted, and the primary goal of pollutes soil management is to ensure that the sites can be used for new purposes through soil remediation. To date, the remediation of contaminated sites has solely focused on contaminant removal, which causes problems such as cost and secondary ecological disturbance in the remediation process. Sustainable soil remediation is not limited to cost reduction but also seeks to restore soil health, minimize surrounding ecosystem disturbance, and sustain its effects. [6,7].

When soil is remediated by applying the concept of sustainable remediation, the evaluation of remediation efficiency can be adequately done by monitoring changes in contaminants and metabolites and monitoring changes in soil functions before and after soil remediation at the same time [5]. Thus, it is essential to develop indicators that can properly monitor the reduction of pollutants and soil quality recovery. Dale and Beyeler [8] stated that good ecological indicators meet the following criteria: easy measurements, sensitivity to managements and environmental changes, the ability to produce consistent, reproducible, and predictable responses to the changes, and low variability in response. Moreover, indicators should provide representative, standardized, and reproducible responses that reflect the extent of soil disturbance or its recovering [4].

It can be said that soil enzymes can be a corresponding ecological indicator for the requirements already mentioned. Soil enzymes can reveal ecosystem perturbations, as they are sensitive to management practices, and have been used as indicators of biogeochemical cycles, organic matter (OM) degradation, and soil remediation. Thus, they can represent soil quality, especially in combination with other physical or chemical properties $[9,10]$. Many studies have been published on the use of soil enzyme activities as ecological indicators of soils affected by contamination, such as toxic trace elements (TTEs), stress conditions, and management practices [11-17]. Soil enzymes can be used as biological indicators for diagnosing soil quality because of their stability and sensitivity; they can well indicate whether the biochemical reactions in the soil to which soil enzymes are involved are correctly performed [18-21]. Recently, efforts have been made to develop appropriate biological indicators to diagnose pollution and monitor the remediation effectiveness for sustainable remediation in Korea.

The main objective of this paper is a review of the recent research related to utilizing the activity of soil enzymes in monitoring the soil pollution and remediation process of contaminated soil. The specific objectives are (1) to explain the influence of TTEs and petroleum hydrocarbons (PHCs) on enzymatic activity in the soil, and (2) to evaluate the usefulness of soil enzymes for monitoring the recovery process of contaminated soil.

\section{Responses of Soil Enzymes to Soil Contamination}

Soil enzymes are primarily known to originate from microorganisms and some from residues of plants or animals. Enzymes accumulate in the soil as free enzymes or stabilized on clay surfaces and/or soil organic matter [5]. Most enzymes that are frequently used to evaluate the effects of TTEs and PHCs pollution can be divided into two groups: oxidoreductases [such as dehydrogenase (DH)] and hydrolases [such as $\beta$-glucosidase (GLU), phosphatase (PHO), urease (UR) and arylsulfatase (ARYL)] [18].

Several mechanisms have been proposed to explain the inhibitory/stimulatory effects of pollutants such as TTEs and PHCs on soil enzyme activity. Direct reversible or irreversible inhibition of soil enzyme activities, pollutants inhibit enzyme activity through the masking of catalytically active groups, denaturing effects on protein conformation. Similar inhibitory effects are shown by the degradation products of organic compounds or anionic TTEs. Pollutants may react competitively to the substrate of enzymes, thus hindering the activity of enzymes [22,23]. The indirect inhibitory action of contaminants is made by causing changes in the microbial community, i.e., size, structure, and functionality [24]. 
Rao et al. [5] also stated that pollutants entering the soil cause measurable changes, as evidenced by alteration in the functions, the biodiversity of soil organisms, and by altered production of enzymes.

\subsection{Contamination with Toxic Trace Elements}

The responses of soil enzymes to TTEs vary greatly, and selecting soil enzymes that are sensitively reactive to TTEs is crucial for diagnosing soil quality. To date, no specific enzyme has been developed as an indicator that can be used universally in various environmental conditions makes it difficult to diagnose soil quality based on soil enzymes.

In general, there are negative correlations between the concentration of TTEs and soil enzyme activity. Thus, soil enzyme assays have often been applied for discriminating pollution levels, providing useful indicators for detecting TTE pollution in soils $[20,25,26]$. Ascertaining whether the reduction in soil enzyme activity due to TTEs involves direct inhibition, reduction of enzymatic synthesis or release, or their combined effects, is nearly impossible $[27,28]$.

Some soil enzyme activities were seriously inhibited by TTEs, but the inhibition diminished over time $[29,30]$. This phenomenon may represent microbial resistance, as the sudden exposure of microorganisms to TTEs results in a significant decrease in enzyme activity; later, microorganisms adapt to the polluted environment, and their enzyme activities tend to recover. The aging effect is also involved in microbial resistance. During aging, pollutants that were initially surface-sorbed are slowly redistributed to the interiors of soil aggregates, including in micropores, with a small proportion diffusing into solid particles, from which desorption is slow and difficult. These contaminants thus become inaccessible to microorganisms.

Microbial processes and enzyme activity mainly depend on the bioavailability of TTEs. Numerous studies have demonstrated that the biological effects of pollutants are not related to the total concentration of a contaminant in soils [31,32]. Instead, organisms respond only to the fraction that is biologically available (bioavailable) to that organism. This is particularly true in soils in which contaminant molecules interact with the soil particles such that the contaminant cannot be taken up by organisms or is present in a non-available form (sometimes referred to as sequestration or irreversible sorption). ISO (International Standardization Organization) 11074 [30] defines the concept of bioavailability as follows: "Bioavailability is the degree to which chemicals present in the soil may be absorbed or metabolized by human or ecological receptors or are available for interaction with biological systems."

Lee et al. [29] reported significant correlations between soil physico-chemical properties and soil enzyme Dehydrogenase, Phosphatase, and Urease (DH, PHO, and UR) activities (Table 1).

Table 1. Correlation matrix of the soil enzyme activity and soil properties.

\begin{tabular}{|c|c|c|c|c|c|c|}
\hline & $\mathrm{OM}^{\mathrm{a}}$ & CEC & Clay & $\mathrm{DH}$ & PHO & UR \\
\hline $\mathrm{pH}$ & $-0.665^{* *}$ & $-0.741^{* *}$ & $0.768^{* *}$ & $-0.704^{* *}$ & $-0.875^{* *}$ & $-0.784 * *$ \\
\hline $\mathrm{OM}$ & & $0.855^{* *}$ & $0.563 * *$ & 0.580 ** & $0.698^{* *}$ & $0.603 * *$ \\
\hline CEC & & & $0.819 * *$ & $0.536^{* *}$ & $0.810^{* *}$ & $0.790 * *$ \\
\hline Clay & & & & $0.636^{* *}$ & $0.873 * *$ & $0.930 * *$ \\
\hline DHA & & & & & $0.804^{* *}$ & $0.682 * *$ \\
\hline PME & & & & & & $0.959 * *$ \\
\hline
\end{tabular}

${ }^{*}$ Correlation is significant at the 0.05 level; ${ }^{* *}$ Correlation is significant at the 0.01 is for $p<0.01 .{ }^{\text {a }} \mathrm{OM}$, Organic Matter; CEC, Cation Exchange Capacity; DH, Dehydrogenase; PHO, Phosphatase; UR, Urease. Source: Adapted from Lee et al. [29].

As a soil core parameter, soil $\mathrm{pH}$ plays a key role in the activity of soil enzymes, soil $\mathrm{pH}$ controls sorption in soil various compounds and regulates various biochemical reactions of soil. In general, an increase in soil $\mathrm{pH}$ leads to an increase in the sorption in soil and a decrease in the availability 
of TTEs. Soil OM is a complex polymeric mixture arising from microbial and chemical degradation processes, the exact structure of which has not been fully elucidated. OM has a high binding affinity for some TTEs in soils and thus reduces their availability.

Pérez de Mora et al. [14] reported that increasing $\mathrm{pH}$ from 3.78 to the range of 4.74-7.35 with organic amendments increased microbial activity. At the same time, the increase in soil $\mathrm{pH}$ caused a reduction in the available TTE fraction, which in turn reduced TTE toxicity to microorganisms. The increases in $\mathrm{pH}$ and OM content induced by the addition of the amendments initially favored TTE precipitation. These changes may also have increased TTE sorption and a decrease in the bioavailable fraction, thereby mitigating the toxicity of TTEs to microorganisms.

Lee et al. [33] reported that $\mathrm{Ca}\left(\mathrm{NO}_{3}\right)_{2}$-extractable $\mathrm{As}, \mathrm{Cd}, \mathrm{Pb}$, and $\mathrm{Zn}$ were reduced significantly after combined treatment with limestone and red mud. The decrease in TTE availability was accompanied by an increase in microbial activities, including respiration, glucose mineralization, and soil enzyme (DH, PHO, UR) activities. Bhattacharyya et al. [34] evaluated the effects of long-term irrigation using sewage contaminated with heavy metals on microbial and biochemical parameters; they reported that the enzymes GLU, UR, and PHO were significantly and negatively correlated with water-soluble and exchangeable forms.

\subsection{Contamination with Petroleum Hydrocarbons}

Although available information on the effects of petroleum hydrocarbons on soil microbial and biochemical parameters is limited, PHC toxicity is influenced by PHC type [33,35].

The introduction of PHCs (such as diesel and gasoline) to soils, i.e., contamination, can provide significant sources of carbon to support microbial growth and activity [36]. Thus, such additions contribute to more significant microbial biomass carbon (MBC). More massive fraction application leads to higher MBC than lighter fraction treatment, which may be due to the lower toxicity of diesel as a carbon source. Higher concentrations of low-boiling-point and unsaturated compounds, aromatics, and acids indicate hydrocarbons that are more toxic to microorganisms in the soil [37]. The toxicity of hydrocarbons is known to cause damage to plasma membranes, with lighter fractions producing greater disruption than heavier fractions $[38,39]$. The physical properties of hydrocarbons play a key role in their behavior in soils. The light fraction is more volatile than the heavy fraction and is more volatile in open systems where hydrocarbons may be lost to the atmosphere. Thus, increased toxicity, decreased availability of short-chain hydrocarbons [40], and decreased total hydrocarbon levels (as potential carbon sources) all contribute to the reduced microbial biomass carbon in soils treated with lighter fractions. Recently contaminated soil contains readily biodegradable and volatile compounds such as n-alkanes $(<\mathrm{n}-\mathrm{C} 21)$ and low-molecular-weight aromatic compounds such as BTEX (benzene, toluene, ethylbenzene, and xylene). Later, the residual hydrocarbons comprise mostly compounds that are recalcitrant and resistant to biodegradation. When the concentration of readily available substrates decreases below a critical level, microorganisms shift toward the production of enzymes to regenerate nutrients from OM; the reverse is also true, as enzymatic production is suppressed when sufficient hydrolysis products are available to meet microbial demands.

Crude oil and some heavier oil fractions, if present at very high concentrations, may block enzyme activity by coating organo-mineral and cell surfaces and thereby preventing soluble substrates from reaching the enzyme molecules. Wang et al. [41] reported soil enzyme measurement results, indicating that $1000 \mathrm{mg} \mathrm{kg}^{-1}$ residual mixed hydrocarbon was the threshold level for stimulating or inhibiting the activities of $\mathrm{PHO}, \mathrm{DH}$, and UR.

\section{Contaminated Soil Recovering Process Monitoring with Soil Enzymes}

Many examples of the application of soil enzymes to evaluate the results of contaminated site restoration have been reported. Soil enzymes are used to evaluate the content of pollutants or intermediate products that remain after remediation as well as to evaluate and monitor the remediation process or remediated soil quality. 


\subsection{Toxic Trace Elements Contaminated Soil}

TTEs are a group of toxic elements that are important industrially. TTEs are released into soils from both natural and anthropogenic sources. Extensive soil pollution caused by TTEs is a key environmental problem at present, threatening environmental quality and human health. Widespread contamination of soils with heavy metal(loid)s is currently one of the most severe environmental problems, seriously affecting environmental quality and human health. In contrast to organic contaminants, TTEs are highly resistant to both biological and chemical degradation.

Developing innovative and site-specific remediation technologies that can feasibly and efficiently remediate TTE-contaminated soils is imperative. Recently, various TTE-contaminated soil remediation technologies have been developed and applied. (Table 2).

Compared with other remediation methods, in situ stabilization is a cost-effective and eco-friendly remediation technology that reduces TTE mobility and availability, either via precipitation or increased sorption. And it has the advantage of minimizing the generation of by-products and disturbance in soil ecology during the remediation process. Therefore, these methods are suitable for remediation (reclamation) of extensive areas of low-value lands, such as mining areas in Korea [42].

Soil amendments (stabilizer) used in soil stabilization reduces the mobility and availability of pollutants and ultimately mitigates the harmful effects of pollutants on the soil organic organisms and the surrounding environment, including humans. Using this technique, the goal of remediation is not to remove TTEs but to stabilize the species that are present by changing the chemical properties of the soil. Total TTEs content is a poor indicator of in situ stabilization, and the solubility and bioavailability of TTEs are more important, as both represent the most labile fractions that are subject to leaching and affecting organisms. Efficient in situ stabilization of TTEs may benefit soil functionality by reducing the labile pools of TTEs, and the dynamics and restoration of soil ecosystem processes using this method have been the subject of systematic research. To assess the recovery of contaminated soil, one must consider not only soil chemical characteristics but also additional assays that can measure the restoration of soil habitat function that are needed. As mentioned above, the stabilization technology does not reduce the total amount of pollutants, so chemical evaluation alone cannot properly evaluate their efficiency. Monitoring indicators should be applied simultaneously to assess the recovery of soil functions due to the stabilization of pollutants, namely the reduction of mobility and (bio)availability $[32,43]$.

Table 2. Soil enzyme activity monitoring results of remediation technologies in toxic trace elements (TTEs) contaminated soil.

\begin{tabular}{|c|c|c|c|}
\hline $\begin{array}{l}\text { Remediation } \\
\text { Technologies }\end{array}$ & Technology Description & Enzyme Activity Monitoring a & Ref. \\
\hline In-situ stabilization & $\begin{array}{l}\text { Decrease in the mobility and } \\
\text { (bio)availability of TTEs in soil based on } \\
\text { amendment addition to contaminated } \\
\text { soils. TTEs can be immobilized in soil } \\
\text { via complexation, precipitation, and } \\
\text { adsorption }\end{array}$ & $\begin{array}{c}\text { Strong negative correlations were } \\
\text { observed between extractable TTE } \\
\text { contents and soil enzyme activities } \\
\text { (DH, UR, PHO); reduced extractable } \\
\text { TTE contents resulted in increased } \\
\text { soil enzyme activities. }\end{array}$ & {$[14,32]$} \\
\hline Soil washing & $\begin{array}{c}\text { Recovery of TTEs via physical } \\
\text { separation and chemical extraction }\end{array}$ & $\begin{array}{l}\text { DH, GLU, PHO, and ARYL } \\
\text { activities decreased after TTE } \\
\text { removal. } \\
\text { Significantly lower DH and PHO } \\
\text { activities in washed soils due to } \\
\text { acidic pH, excessive nutrient } \\
\text { contents, or both. }\end{array}$ & {$[44,45]$} \\
\hline Electrokinetics & $\begin{array}{l}\text { Direct electric field application in soil to } \\
\text { drive pollutants within soil pores } \\
\text { toward the electrode via } \\
\text { electromigration, electroosmosis and } \\
\text { electrophoresis. }\end{array}$ & $\begin{array}{l}\text { Significantly decreased UR activity, } \\
\text { resulting from the electrolyte } \\
\text { changes. }\end{array}$ & {$[46]$} \\
\hline
\end{tabular}


Lee et al. [34] reported that lowering the concentrations of the exchangeable fraction of TTEs may reduce the possible detrimental effects of TTEs on soil enzyme activity. Strong negative correlations were observed between $\mathrm{Ca}\left(\mathrm{NO}_{3}\right)_{2}$-extractable TTE contents and soil microbiological parameters (soil respiration, $\mathrm{UR}, \mathrm{PHO})$. $\mathrm{Ca}\left(\mathrm{NO}_{3}\right)_{2}$ - extraction method is considered as the measuring method that measure the mobility and bioavailability of TTEs in the soil.

In another study, Pérez de Mora et al. [14] reported that organic amendments improved soil chemical properties by increasing soil $\mathrm{pH}$, total organic carbon content, and water-soluble carbon content in the amended soils while reducing soluble TTE concentrations. At the same time, higher MBC levels, enzyme activities, and maximum glucose mineralization rates were measured in organic amendments amended soils.

Pardo et al. [47] evaluated the effects of amendments on soil biochemical and ecotoxicological properties and their relationships with the major physicochemical characteristics of soil and porewater. They reported that the original soil showed impaired essential ecological functions due to the high availability of TTEs, acidic $\mathrm{pH}$, and high salinity. The two organic amendments (pig slurry and compost) evaluated reduced the direct and indirect toxicity of soil to plants, invertebrates, and microorganisms by reducing TTE mobility in topsoil and the associated risks. The organic amendments tested in that study, especially compost, which supplied essential nutrients, improved soil health by stimulating plant growth and significantly increased enzyme activities (GLU and UR) related to key soil nutrients. Furthermore, the use of organic amendments decreased soil ecotoxicity and appears to be a suitable management strategy for the remediation of highly acidic TTE-contaminated soils.

Soil washing is a soil remediation technology that removes pollutants by separating them from the soil by physical separation and chemical leaching, and various reagents and extractants are used for chemical leaching [48]. Applying of soil washing for remediating TTEs-contaminated soils has been common, as this remediation technology completely removes pollutants such as TTEs from the soil. During the soil washing process, contaminants are separated from the soil through various mechanisms, i.e., precipitation, ion exchange, and adsorption, TTEs in the soil are transferred to the liquid phase, and then the soil is separated from the leachate [49]. Separated soil that meets regulatory criteria can be backfilled at the original site. The application of soil washing technology based on physical separation and chemical extraction inevitably entails changes in soil properties related to soil quality [44]. For example, soil properties such as soil texture, water holding capacity (WHC), OM content, and nutrients such as total nitrogen concentration were altered after soil washing [44]. Inevitably accompanied changes in the physico-chemical properties (e.g., $\mathrm{pH}, \mathrm{OM}$, and clay content) of soil during the soil washing process reflect changes in the bioavailability of TTEs in soils [50].

Im et al. [45] reported that washed soils may exhibit toxic effects. Nevertheless, contaminant concentrations are reduced, ecological properties (soil enzyme activities; DH, PHO, and GLU) did not recover completely after TTEs were removed from the soil because of adverse changes in soil physicochemical properties. Furthermore, the ecotoxicological characteristics of the washed soils had strong relationships with changes in soil properties such as soil $\mathrm{pH}$ and nutrient concentrations. Similarly, the removal of TTEs by soil washing could result in the loss of soil microorganisms, soil OM, and nutrients.

Yi and Sung [44] observed that DH, GLU, PHO, and ARYL failed to recover after TTE removal, indicating changes in the physicochemical properties of the soil. Chae et al. [51] evaluated the toxicity of remediated soils located near a non-ferrous metal smelter by measuring the activity levels of eight soil exoenzymes and reported that the activities of most enzymes decreased after remediation (soil washing), whereas that of UR increased. The authors attributed this result to nitrogen limitation in the remediated soil and recommended the use of GLU activity as a prior indicator for estimating soil ecosystem health by principal component analysis.

Another case, Kaulin et al. [52], reported that remediation had a positive effect on DH and GLU activities (associated with the carbon cycle) and that UR activity decreased after washing with ethylenediaminetetraacetic acid. They suggest that enzyme activity is sensitive not only to 
soil remediation but also to transient soil conditions, such as substrate addition. The mechanisms underlying the relationships among substrate composition, diversity, abundance, and activity are specific to each enzyme. Substrate quantity alone therefore, may not increase the activity of a given extracellular enzyme.

Changes in soil physicochemical properties after soil-washing treatments have been examined to investigate the effects of these processes on the ecological properties of soils. Physical separation during soil washing led to decreasing clay contents, and chemical extraction processes also altered soil chemical properties due to the reagents used and caused changes in the nutrients and pollutants availability following overall soil quality deteriorated, consequently. Therefore, such changes in soil properties should be considered when considering the reuse or recycling of remediated soils. Improving soil quality might facilitate the recycling of remediated soils [44].

Electrokinetics is a physical method for the extraction of chemicals from contaminated sites and can be used for in situ treatment of inorganic and organic pollutants [53]. Its operating principle is to direct the application of an electric field to the soil to drive pollutants within the soil pores toward an electrode via electromigration, electroosmosis, and electrophoresis. The application of direct electric current to soil results in changes to several soil characteristics, such as $\mathrm{pH}$, redox potential, and electrolyte concentration, and these changes may affect the chemical nature of the clay surface and the success of electrokinetics remediation $[54,55]$. Typically, the application of electrokinetics induces a $\mathrm{pH}$ gradient across the bioreactor cell $[56,57]$ due to electrolytic reactions that produce protons at the anode, leading to an acid front that advances toward the cathode. Although the electrolytic generation of hydroxyl ions can be neutralized within the catholyte, the accompanying decrease in $\mathrm{pH}$ may drive changes in soil microbial activity and distribution [54]. Soil $\mathrm{pH}$ is a crucial parameter affecting soil microbial growth via influences on a complex range of interacting factors, including membrane integrity and function as well as the bioavailability of nutrients and pollutants. The direct effects of the applied current on soil bacteria could not be ascertained, as they were inseparable from other electrochemically induced soil changes. Lear et al. [58] found that the application of electrokinetics altered both its physicochemical characteristics and the exposed microbial community. And elucidating the interactions between electrokinetic processes and microbial communities in the soil is essential for improving the efficacy and sustainability of this remediation strategy.

Wang et al. [46] reported that nitrogen cycling was altered in soils after electrokinetic treatment, with the restored soils showing significantly lower enzyme activities than those in clean soil, indicating that these soils were not fully restored. In particular, UR activity remained affected after electrokinetic treatment, and soil UR activity was significantly correlated with other biological indicators, such as the results of earthworm tests and ryegrass root elongation, validating soil UR activity as an indicator for ecological assessment of soil toxicity after electrokinetic remediation.

\subsection{Petroleum Hydrocarbons Contaminated Soil}

Removal of PHCs from soil can be accomplished by a combination of chemical oxidation, photo-oxidation, evaporation, and microbial oxidation (biodegradation, mineralization). In general, microbiological oxidation, mineralization, is a key step in PHCs decontamination, as one or more above processes are involved in the decomposition of PHCs in combination, depending on the timeline (aged/fresh) and various environmental factors. Biodegradation of PHCs by natural populations of microorganisms is well understood, with numerous bacteria and fungi mineralizing hydrocarbons and degrading PHCs under both aerobic and anaerobic conditions [59,60].

Biological monitoring of the bioremediation process has been mainly conducted on soil respiration, DH activity, and microbial numbers [61]. Soil enzymes have played a key role in the circulation of nutrients and have been used as a biological indicator of the hydrocarbon remediation process $[20,61]$. Many studies have shown that simultaneous measurement of the activities of several enzymes in soil may be more valid than the measurement of a single enzyme for evaluating overall microbial activity, as well as its responses to diffuse pollution and environmental stress (Table 3). 
Table 3. Examples of PHCs contaminated soil recovering processes monitoring using soil enzyme activity.

\begin{tabular}{|c|c|c|c|}
\hline $\begin{array}{l}\text { Remediation } \\
\text { Technologies }\end{array}$ & Technology Description & Enzyme Activity Monitoring a & Ref. \\
\hline Bioremediation & $\begin{array}{l}\text { Bioremediation is enhanced by either } \\
\text { bioaugmentation, which involves } \\
\text { inoculation of exogenous } \\
\text { microorganisms into } \\
\text { petroleum-contaminated soil, or } \\
\text { biostimulation, in which nutrients are } \\
\text { provided to the soil to stimulate the } \\
\text { hydrocarbon-degrading capacity of } \\
\text { indigenous microorganisms. }\end{array}$ & $\begin{array}{l}\text { DH, UR, and PHO activities } \\
\text { increased immediately after oil } \\
\text { contamination but decreased with } \\
\text { decreasing hydrocarbon content; } \\
\text { DH activity was depressed } \\
\text { significantly due to } \\
\text { hydrocarbon toxicity. } \\
\text { UR and DH had significant } \\
\text { correlations with residual PHCs. }\end{array}$ & {$[13,15,61]$} \\
\hline Thermal desorption & $\begin{array}{l}\text { Utilizes heat to increase the volatility of } \\
\text { contaminants so that they can be } \\
\text { removed (separated) from the solid } \\
\text { matrix; the volatilized contaminants are } \\
\text { then either collected or } \\
\text { destroyed thermally. }\end{array}$ & $\begin{array}{l}\text { The heat-induced reductions in soil } \\
\text { OM, clay content and pH can reduce } \\
\text { cation exchange capacity and WHC, } \\
\text { which may consequently degrade } \\
\text { soil quality. }\end{array}$ & {$[62,63]$} \\
\hline
\end{tabular}

${ }^{a}$ DH, dehydrogenase activity; UR, urease activity; PHO, phosphatse activity.

Margesin et al. [64] found significant correlations between soil biological parameters and the levels of hydrocarbon residues, indicating that biological parameters help elucidate the microbial contribution to hydrocarbon elimination from the soil. Due to the complexity of the PHCs degradation process, chemical analysis alone has limitations in obtaining sufficient information, single and combined chemical and ecotoxicity assays have been strongly recommended for evaluating the effectiveness of remediation in various types of PHCs-contaminated soil $[65,66]$.

$\mathrm{UR}, \mathrm{DH}, \mathrm{PHO}$, etc. are representative enzymes that have been used to monitor the oil-contaminated soil purification process, and in many studies, the activity of these enzymes has been observed to increase in activity in the early stages compared to non-contaminated soil and to decrease over time. Some studies have used UR, DH, and PHO as representative enzymes for monitoring hydrocarbon decontamination before and after bioremediation. These levels of enzymes, relative to those in uncontaminated soil, were initially elevated and then decreased over time [13].

Lee et al. [67] conducted bioremediation of aged heavy mineral oil (lubricants) using nutrient addition (biostimulation) and monitored changes in soil enzyme activities during the process. DH activity increased substantially during the early stage but showed no significant change throughout the study period in non-fertilized soil. Furthermore, the authors reported that the biodegradation of aged heavy mineral oil (lubricants) can be monitored readily based on soil biological parameters, such as soil respiration, number of hydrocarbon-utilizing bacteria, and DH activity. Lee et al. [67] suggested that soil enzyme activity should be applied to complement chemical methods for evaluation and assessment of the decontamination process for aged heavy mineral oil.

Polyak et al. [11] reported that soil DH activity was significantly higher in control soil than in contaminated soil and they attributed that the low DH activity reflects the toxic effects of PHCs on the process of PHC's dehydrogenation. The activity of DH is increased or inhibited by the introduction of PHCs, and the impact of PHCs affecting DH activities is known to vary depending on PHC's concentration and environmental conditions [65-67]. Bioremediation increases the activity of UR, with the most significant effect observed under conditions of bioaugmentation, although a powerful and positive initial impact on UR activity was also produced by the addition of nutrients $[11,68]$. Polyak et al. [11] also reported DH is one of the principal agents involved in the degradation of soil PHCs, as it is involved in the transport of electrons and hydrogen through a chain of intermediate electron carriers to a final electron acceptor (oxygen). DH is an intracellular enzyme common to most organisms and is considered the best indicator of the oxidative potential of soil [11,20,69].

Ramadass et al. [70] reported that DH, UR, and invertase decreased with increasing content of a hydrocarbon mixture at $<1000 \mathrm{mg} \mathrm{kg}^{-1}$ and decreased to zero when the hydrocarbon concentration 
was $>1000 \mathrm{mg} \mathrm{kg}^{-1}$. The enzymes catalase and PHO were stimulated at hydrocarbon levels below $1000 \mathrm{mg} \mathrm{kg}^{-1}$ and were inhibited above that level. The differences in these changes among soil enzymes may be related to contaminant type and soil characteristics [37].

Among the soil remediation technologies being developed, the thermal desorption can deal with petroleum pollutants quickly and reliably if properly applied. Thermal desorption of organic pollutants such as PHCs is carried out through various mechanisms such as oxidation, incineration, thermal cracking, and pyrolytic, which can be applied according to temperature and oxygen content. [71]. High-molecular-weight hydrocarbons in the presence of low oxygen levels are pyrolyzed at thermal desorption temperatures between $300^{\circ} \mathrm{C}$ and $550^{\circ} \mathrm{C}$, whereas hydrocarbons in the presence of excess oxygen are incinerated at thermal desorption temperatures between $100^{\circ} \mathrm{C}$ and $300^{\circ} \mathrm{C}$. As thermal desorption or pyrolysis of contaminants occurs when the soils are heated under anoxic (without oxygen) or hypoxic (low oxygen) conditions, the soil may reach high temperatures of $800{ }^{\circ} \mathrm{C}$ to $900{ }^{\circ} \mathrm{C}$, at which hydrocarbons undergo thermal cracking.

Many studies of thermal desorption for PHC-contaminated soils conducted to date have been performed at high temperatures, which has the advantage of being easy to achieve the cleanup goal, but also have the disadvantage of low energy efficiency. Although the high-temperature thermal desorption (HTTD) has the advantage of being able to easily achieve the purification goal, the problem is that the energy efficiency is low and that it is difficult to achieve sustainable remediation due to the significant deterioration of the physico-chemical characteristics of the soil in the processing process. However, high temperatures induce changes in soil properties, which is an obstacle to sustainable remediation of PHC-contaminated soils. Since changes in soil quality-related characteristics such as $\mathrm{OM}$ content, $\mathrm{pH}$, and water holding capacity (WHC) occur during the thermal desorption process, it is necessary to evaluate soil enzyme activity that can monitor soil quality changes during the remediation process.

Soil enzymes activities generally increase up to $70{ }^{\circ} \mathrm{C}$, but at higher temperatures, activity is suppressed by the denaturation of proteins, and it is known to inhibit the PHO activity due to the increase in soil $\mathrm{pH}$ and available phosphorus content induced by heat [72]. Reducing in easily degradable carbon levels can reduce some carbon-acquiring enzymes, such as GLU activity [73]. The presence of contaminants and shifts in the microbial community also influence the response of enzymes to heating [63].

Pape et al. [63] reported that a critical temperature threshold was observed at $500{ }^{\circ} \mathrm{C}$ and that treatments conducted below this temperature are amenable to biological recovery (increased enzyme activity) and support plant growth, while inoculation with an appropriate microbial community improves the recovery of specific biological processes in the soil. And they reported that above $500{ }^{\circ} \mathrm{C}$, the loss of $\mathrm{OM}$ and nitrogen was remarkable, so the soil function after remediation, i.e. as a medium for plant growth, was not restored, and minimal microbial re-colonization. Furthermore, they reported that an additional supply of OM, nitrogen-fixed microorganisms, and nutrients are needed to restore soil function if soil quality has significantly deteriorated.

Recently, some efforts at low-temperature thermal desorption (LTTD, typically operated at $100-350^{\circ} \mathrm{C}$ ) have been made to improve energy efficiency and minimize adverse effects on soil properties; hence, LTTD has great potential as a sustainable remediation technology for diesel-contaminated soils [74]. Ren et al. [74] reported that LTTD quickly and effectively remediated diesel-contaminated soils and this treatment improved soil reusability by preserving the OM content, $\mathrm{pH}$, and WHC while increasing $\mathrm{NO}_{3}-\mathrm{N}$ and $\mathrm{NH}_{4}-\mathrm{N}$ levels. LTTD-treated contaminated soil was suitable for plant growth. The microbial community shifted substantially with LTTD and recovered after mixing with uncontaminated soil.

Yi et al. [62] reported that the total petroleum hydrocarbon (TPH) level, electrical conductivity, and $\mathrm{OM}$ content decreased, whereas the WHC and available $\mathrm{P}_{2} \mathrm{O}_{5}$ level increased by LTTD treatment. They also noted that LTTD improved overall soil health in terms of biological productivity and environmental functions, suggesting that LTTD provides an alternative to harsher remediation such 
as HTTD. However, the ecological properties of treated soils still showed differences relative to the adjacent non-contaminated soils. Thus, changes in eco-physiochemical properties should be considered to ensure safe soil reuse. DH activity increased following LTTD but remained lower than that of non-contaminated control soil, showing that soil ecological functions require further improvement to restore the soil functions fully.

Wang et al. [41] observed strong relationships between soil enzymatic activities and residual (after thermal desorption) hydrocarbon levels. They found that the DH and UR activities were stimulated at hydrocarbon levels $<1000 \mathrm{mg} \mathrm{kg}^{-1}$ and inhibited above that level. In addition, soil enzymatic activities responded to the removal of hydrocarbon mixtures in thermally treated soil and thus could be used to assess the residual hydrocarbon content after thermal treatment. A combination of biological and chemical data would support meaningful and comprehensive assessments of thermally treated remediation sites over time.

\section{Conclusions and Future Perspectives}

All results reported so far have been described briefly, and the availability of soil enzymes as an indicator of environmental management is beyond question. Soil enzyme activities are useful indicator factors in diagnosing the degree of damage to soil functions caused by contamination and monitoring the recovery of soil functions during the soil remediation process. Along with other biological and chemical properties, enzyme activities may provide useful information about the responses of soil to the disturbance caused by contamination and support assessment of whether and to what extent the soil has regained its health conditions.

Biological indicators generally play an important role in determining remedial endpoints for hazard assessment and remediation. Complete detoxification of contaminated soils may require further treatment, which should be evaluated based on soil health [46]. The sensitivity of enzymes as indicators for both pollution evaluation and monitoring of contaminated soil recovery is higher for oxidoreductases than hydrolases. Yang et al. [18] reported that oxidoreductases can be used as core bioindicator enzymes, and hydrolases can be used as auxiliary enzymes related to carbon, nitrogen, and phosphorus recycling. Soil properties are highly heterogeneous, and therefore these suggestions require validation over a long period and across various polluted areas.

Quantitative relationships between soil physico-chemical properties (soil $\mathrm{pH}$, clay, and $\mathrm{OM}$ content, etc.) and enzyme activities may require further attention and investigation. Further studies on such quantitative relationships may help to achieve consistent results from enzymatic diagnosis of soil quality. Identification of suitable soil quality indicators for the evaluation of the performance of soil functions in remediation projects is a priority topic for future research. This review shows the need for further investigations aimed at establishing the potential negative and positive impacts of various remediation technologies on soil quality in the context of soil functions.

Author Contributions: Methodology S.-O.K.; writing-original draft preparation S.-H.L.; writing-review, M.-S.K., J.-G.K. All authors have read and agreed to the published version of the manuscript.

Funding: This research was funded by Korean Environment Industry \& Technology Institute (KEITI) through "Subsurface Environment Management (SEM) Projects," funded by Korea Ministry of Environment (RE202002041).

Conflicts of Interest: The authors declare no conflict of interest. The funders had no role in the design of the study; in the collection, analyses, or interpretation of data; in the writing of the manuscript, or in the decision to publish the results.

\section{References}

1. Brombal, D.; Wang, H.; Pizzol, L.; Critto, A.; Giubilato, E.; Guo, G. Soil environmental management systems for contaminated sites in China and the EU Common challenges and perspectives for lesson drawing. Land Use Policy 2015, 48, 286-298. [CrossRef]

2. Ndiaye, E.L.; Sandeno, J.M.; McGrath, D.; Dick, R.P. Integrative biological indicators for detecting change in soil quality. Am. J. Altern. Agric. 2000, 15, 26-36. [CrossRef] 
3. Gómez-Sagasti, M.T.; Alkorta, I.; Becerril, J.M.; Epelde, L.; Anza, M.; Garbisu, C. Microbial monitoring of the recovery of soil quality during heavy metal phytoremediation. Water Air Soil Pollut. 2012, 223, 3249-3262. [CrossRef]

4. Doran, J.W.; Zeiss, M.R. Soil health and sustainability: Managing the biotic component of soil quality. Appl. Soil Ecol. 2000, 15, 3-11. [CrossRef]

5. Rao, M.A.; Scelza, R.; Acevedo, F.; Diez, M.C.; Gianfreda, L. Enzymes as useful tools for environmental purposes. Chemosphere 2014, 107, 145-162. [CrossRef] [PubMed]

6. Hou, D.; Al-Tabbaa, A. Sustainability: A new imperative in contaminated land remediation. Environ. Sci. Policy 2014, 39, 25-34. [CrossRef]

7. Holland, K.S. A framework for sustainable remediation. Environ. Sci. Technol. 2011, 45, 7116-7117. [CrossRef] [PubMed]

8. Dale, V.H.; Beyeler, S.C. Challenges in the development and use of ecological indicators. Ecol. Indic. 2001, 1, 3-10. [CrossRef]

9. Gelsomino, A.; Badalucco, L.; Landi, L.C.G. Soil carbon, nitrogen and phosphorus dynamics as affected by solarization alone or combined with organic amendment. Plant Soil 2006, 279, 307-325. [CrossRef]

10. Topac, F.O.; Dindar, E.; Ucaroglu, S.; Baskaya, H.S. Effect of a sulfonated azo dye and sulfanilic acid on nitrogen transformation processes in soil. J. Hazard. Mater. 2009, 170, 1006-1013. [CrossRef]

11. Polyak, Y.M.; Bakina, L.G.; Chugunova, M.V.; Mayakina, N.V.; Gerasimov, A.O.; Bure, V.M. Effect of remediation strategies on biological activity of oil-contaminated soil-A field study. Int. Biodeterior. Biodegrad. 2018, 126, 57-68. [CrossRef]

12. Khalid, S.; Shahid, M.; Khan Niazi, N.; Murtaza, B.; Bibi, I.; Dumat, C. A comparison of technologies for remediation of heavy metal contaminated soils. J. Geochem. Explor. 2017, 182, 247-268. [CrossRef]

13. Maila, M.P.; Cloete, T.E. The use of biological activities to monitor the removal of fuel contaminants-perspective for monitoring hydrocarbon contamination: A review. Int. Biodeter. Biodegrad. 2005, 55, 1-8. [CrossRef]

14. Pérez-de Mora, A.; Ortega-Calvo, J.J.; Cabrera, F.; Madejón, E. Changes in enzyme activities and microbial biomass after "in situ" remediation of a heavy metal-contaminated oil. Appl. Soil Ecol. 2005, 28, 125-137. [CrossRef]

15. Shen, W.; Zhu, N.; Cui, J.; Wang, H.; Dang, Z.; Wu, P.; Luo, Y.; Shi, C. Ecotoxicity monitoring and bioindicator screening of oil-contaminated soil during bioremediation. Ecotox. Environ. Safe. 2016, 124, 120-128. [CrossRef] [PubMed]

16. Dawson, J.J.C.; Godsiffe, E.J.; Thompson, I.P.; Ralebitso-Senior, T.K.; Killham, K.S.; Paton, G.I. Application of biological indicators to assess recovery of hydrocarbon impacted soils. Soil Biol. Biochem. 2007, 39, 164-177. [CrossRef]

17. Carina Niemeyer, J.; Bortoti Lolata, G.; de Carvalho, G.M.; Mendes Da Silva, E.; Sousa, J.P.; Nogueira, M.A. Microbial indicators of soil health as tools for ecological risk assessment of a metal contaminated site in Brazil. Appl. Soil Ecol. 2012, 59, 96-105. [CrossRef]

18. Yang, J.S.; Yang, F.L.; Yang, Y.; Xing, G.L.; Deng, C.P.; Shen, Y.T.; Luo, L.Q.; Li, B.Z.; Yuan, H.L. A proposal of "core enzyme" bioindicator in long-term $\mathrm{Pb}$ - Zn ore pollution areas based on topsoil property analysis. Environ. Pollut. 2016, 213, 760-769. [CrossRef]

19. Liang, Q.; Gao, R.; Xi, B.; Zhang, Y.; Zhang, H. Long-term effects of irrigation using water from the river receiving treated industrial wastewater on soil organic carbon fractions and enzyme activities. Agric. Water Manag. 2014, 135, 100-108. [CrossRef]

20. Gianfreda, L.; Rao, M.A.; Piotrowska, A.; Palumbo, G.; Colombo, C. Soil enzyme activities as affected by anthropogenic alterations: Intensive agricultural practices and organic pollution. Sci. Total Environ. 2005, 341, 265-279. [CrossRef]

21. Hinojosa, M.B.; Carreira, J.A.; García-Ruíz, R.; Dick, R. Soil moisture pretreatment effects on enzyme activities as indicators of heavy metal contaminated soils. Soil Biol. Biochem. 2004, 36, 1559-1568. [CrossRef]

22. Kizilkaya, R.; Bayrakli, B. Effects of N-enriched sewage sludge on soil enzyme activities. Appl. Soil Ecol. 2005, 30, 192-202. [CrossRef]

23. Hu, X.F.; Jiang, Y.; Shu, Y.; Hu, X.; Liu, L.; Luo, F. Effects of mining wastewater discharges on heavy metal pollution and soil enzyme activity of the paddy fields. J. Geochem. Explor. 2014, 147, 139-150. [CrossRef] 
24. Song, J.; Shen, Q.; Wang, L.; Qiu, G.; Shi, J.; Xu, J.; Brookes, P.; Liu, X. Effects of Cd, Cu, Zn and their combined action on microbial biomass and bacterial community structure. Environ. Pollut. 2018, 243, 510-518. [CrossRef] [PubMed]

25. Mench, M.; Renella, G.; Gelsomino, A.; Landi, L.; Nannipieri, P. Biochemical parameters and bacterial species richness in soils contaminated by sludge-borne metals and remediated with inorganic soil amendments. Environ. Pollut. 2006, 144, 24-31. [CrossRef] [PubMed]

26. Renella, G.; Mench, M.; Gelsomino, A.; Landi, L.; Nannipieri, P. Functional activity and microbial community structure in soils amended with bimetallic sludges. Soil Biol. Biochem. 2005, 37, 1498-1506. [CrossRef]

27. Chen, J.; He, F.; Zhang, X.; Sun, X.; Zheng, J.; Zheng, J. Heavy metal pollution decreases microbial abundance, diversity and activity within particle-size fractions of a paddy soil. FEMS Microbiol. Ecol. 2014, 87, 164-181. [CrossRef]

28. Khan, S.; Cao, Q.; Hesham, A.B.; Xia, Y.; He, J. Soil enzymatic activities and microbial community structure with different application rates of $\mathrm{Cd}$ and Pb. J. Environ. Sci. 2007, 19, 834-840. [CrossRef]

29. Lee, S.H.; Kim, E.Y.; Hyun, S.H.; Kim, J.G. Metal availability in heavy metal-contaminated open burning open detonation soil: Assessment using soil enzymes, earthworms, and chemical extraction. J. Hazard. Mater. 2009, 170, 382-388. [CrossRef]

30. ISO 11074. Soil Quality-Vocabulary; International Standardization Organization: Geneva, Switzerland, 2005.

31. Alexander, M. 2000. Aging, bioavailability, and overestimation of risks from environmental pollutants. Environ. Sci. Technol. 2000, 34, 4259-4265. [CrossRef]

32. Lee, S.H.; Kim, E.Y.; Park, H.; Yoon, J.H.; Kim, J.G. In situ stabilization of arsenic and metal-contaminated agricultural soil using industrial by-products. Geoderma 2011, 161, 1-7. [CrossRef]

33. Pena, W.; Trasar-Cepeda, C.; Gil-Sotres, F.; Leiros, M. Modification of the degradative capacity of a soil artificially contaminated with diesel. Chemosphere 2007, 67, 1057-1063. [CrossRef] [PubMed]

34. Bhattacharyya, P.; Tripathy, S.; Chakrabarti, K.; Chakaborty, A.; Banik, P. Fractionation and bioavailability of metals and their impacts on microbial properties in sewage irrigated soil. Chemosphere 2008, 72, 543-550. [CrossRef] [PubMed]

35. Labud, V.; Garcia, C.; Hernandez, T. Effect of hydrocarbon pollution on the microbial properties of a sandy and a clay soil. Chemosphere 2007, 66, 1863-1871. [CrossRef] [PubMed]

36. Bundy, J.G.; Paton, G.I.; Campbell, C.D. Microbial communities in different soil types do not converge after diesel contamination. J. Appl. Microbiol. 2002, 92, 276-288. [CrossRef]

37. Xu, J.G.; Johnson, R.L. Root growth, microbial activity and phosphatase activity in oil-contaminated, remediated and uncontaminated soils planted to barley and field pea. Plant Soil 1995, 173, 3-10. [CrossRef]

38. Fernandes, P.; Sommer Ferreira, B.; Sampaio Cabral, J.M. Solvent tolerance in bacteria: Role of efflux pumps and cross resistance with antibiotics. Int. J. Antimicrob. Agents 2003, 22, 211-216. [CrossRef]

39. Gouda, M.K.; Omar, S.H.; NourEldin, H.M.; Chekroud, Z.A. Bioremediation of kerosene II: A case study in contaminated clay (laboratory and field: Scale microcosms). World J. Microbiol. Biotechnol. 2008, 24, 1451-1460. [CrossRef]

40. Cermak, J.H.; Stephenson, G.L.; Birkholz, D.; Wang, Z.; Dixon, D.G. Toxicity of petroleum hydrocarbon distillates to soil organisms. Environ. Toxicol. Chem. 2010, 29, 2685-2694. [CrossRef]

41. Wang, J.; Zhan, X.; Zhou, L.; Lin, Y. Biological indicators capable of assessing thermal treatment efficiency of hydrocarbon mixture-contaminated soil. Chemosphere 2010, 80, 837-844. [CrossRef]

42. Lee, S.H.; Ji, W.; Yang, H.J.; Kang, S.Y.; Kang, D.M. Reclamation of mine-degraded agricultural soils from metal mining: Lessons from 4 years of monitoring activity in Korea. Environ. Earth Sci. 2017, 76, 720. [CrossRef]

43. Leitgib, L.; Kálmán, J.; Gruiz, K. Comparison of bioassays by testing whole soil and their water extract from contaminated sites. Chemosphere 2007, 66, 428-434. [CrossRef] [PubMed]

44. Yi, Y.M.; Sung, K. Influence of washing treatment on the qualities of heavy metal-contaminated soil. Ecol. Eng. 2015, 81, 89-92. [CrossRef]

45. Im, J.W.; Yang, K.; Jho, E.H.; Nam, K. Effect of different soil washing solutions on bioavailability of residual arsenic in soils and soil properties. Chemosphere 2015, 138, 253-258. [CrossRef]

46. Wang, Q.Y.; Zhou, D.M.; Cang, L.; Sun, T.R. Application of bioassays to evaluate a copper contaminated soil before and after a pilot-scale electrokinetic remediation. Environ. Pollut. 2009, 157, 410-416. [CrossRef] 
47. Pardo, T.; Clemente, R.; Alvarenga, P.; Bernal, M.P. Efficiency of soil organic and inorganic amendments on the remediation of a contaminated mine soil: Ii. Biological and ecotoxicological evaluation. Chemosphere 2014, 107, 101-108. [CrossRef]

48. Guo, X.; Wei, Z.; Wu, Q.; Li, C.; Qian, T.; Zheng, W. Effect of soil washing with only chelators or combining with ferric chloride on soil heavy metal removal and phytoavailability: Field experiments. Chemosphere 2016, 147, 412-419. [CrossRef]

49. Ferraro, A.; van Hullebusch, E.D.; Huguenot, D.; Fabbricino, M.; Esposito, G. Application of an electrochemical treatment for EDDS soil washing solution regeneration and reuse in a multi-step soil washing process: Case of a Cu contaminated soil. J. Environ. Manag. 2015, 163, 62-69. [CrossRef]

50. Huang, R.-Q.; Gao, S.-F.; Wang, W.-L.; Staunton, S.; Wang, G. Soil arsenic availability and the transfer of soil arsenic to crops in suburban areas in Fujian Province, southeast China. Sci. Total Environ. 2006, 368, 531-541. [CrossRef]

51. Chae, Y.; Cui, R.; Kim, S.W.; An, G.; Jeong, S.W. Exoenzyme activity in contaminated soils, before and after soil washing: $\beta$-glucosidase activity as a biological indicator of soil health. Ecotox. Environ. Safe. 2017, 135, 368-374. [CrossRef]

52. Kaurin, A.; Lestan, D. Multi-substrate induced microbial respiration, nitrification potential and enzyme activities in metal-polluted, EDTA-washed soils. Environ. Pollut. 2018, 243, 238-243. [CrossRef] [PubMed]

53. Zhou, D.M.; Deng, C.F.; Cang, L. Electrokinetic remediation of a Cu contaminated red soil by conditioning catholyte $\mathrm{pH}$ with different enhancing chemical reagents. Chemosphere 2004, 56, 265-273. [CrossRef] [PubMed]

54. Lear, G.; Harbottle, M.J.; van der Gast, C.J.; Jackman, S.A.; Knowles, C.J.; Sills, G.; Thompsona, I.P. The effect of electrokinetics on soil microbial communities. Soil Biol. Biochem. 2004, 36, 1751-1760. [CrossRef]

55. Al-Hamdan, A.Z.; Reddy, K.R. Transient behavior of heavy metals in soils during electrokinetic remediation. Chemosphere 2008, 71, 860-871. [CrossRef]

56. Jackman, S.A.; Maini, G.; Sharman, A.K.; Sunderland, G.; Knowles, C.J. Electrokinetic movement and biodegradation of 2,4-dichlorephenoxyacetic acid in silt soil. Biotechnol. Bioeng. 2001, 74, 40-48. [CrossRef]

57. Mattson, E.D.; Bowman, R.S.; Lindgren, E.R. Electrokinetic ion transport through unsaturated soil. 1. Theory, model development and testing. J. Contam. Hydrol. 2002, 54, 99-120. [CrossRef]

58. Lear, G.; Harbottle, M.J.; Sills, G.; Knowles, C.J.; Semple, K.T.; Thompson, I.P. Impact of electrokinetic remediation on microbial communities within PCP contaminated soil. Environ. Pollut. 2007, 146, 139-146. [CrossRef]

59. Marchand, C.; St-Arnaud, M.; Hogland, W.; Bell, T.H.; Hijri, M. Petroleum biodegradation capacity of bacteria and fungi isolated from petroleum-contaminated soil. Int. Biodeterior. Biodegrad. 2017, 116, 48-57. [CrossRef]

60. Mbadinga, S.M.; Wang, L.Y.; Zhou, L.; Liu, J.F.; Gu, J.D.; Mu, B.Z. Microbial communities involved in anaerobic degradation of alkanes. Int. Biodeterior. Biodegrad. 2011, 65, 1-13. [CrossRef]

61. Margesin, R.; Schinner, F. Bioremediation of diesel-oil-contaminated alpine soils at low temperatures. Appl. Microbiol. Biotechnol. 1997, 47, 462-468. [CrossRef]

62. Yi, Y.; Park, S.; Munster, C.; Kim, G.; Sung, K. Changes in ecological properties of petroleum oil-contaminated soil after low-temperature thermal desorption treatment. Water Air Soil Pollut. 2016, 227, 1-10. [CrossRef]

63. Pape, A.; Switzer, C.; McCosh, N.; Knapp, C.W. Impacts of thermal and smouldering remediation on plant growth and soil ecology. Geoderma 2015, 243-244, 1-9. [CrossRef]

64. Margesin, R.; Zimmerbauer, A.; Schinner, F. Monitoring of soil bioremediation by soil biological activities. Chemosphere 2000, 40, 339-346. [CrossRef]

65. Bento, F.M.; Camargo, F.A.O.; Okeke, B.C.; Frankenberger, W.T. Comparative bioremediation of soils contaminated with diesel oil by natural attenuation, biostimulation and bioaugmentation. Bioresour. Technol. 2005, 96, 1049-1055. [CrossRef] [PubMed]

66. Płaza, G.; Nałęcz-Jawecki, G.; Ulfig, K.; Brigmon, R.L. The application of bioassays as indicators of petroleum contaminated soil remediation. Chemosphere 2005, 59, 289-296. [CrossRef] [PubMed]

67. Lee, S.H.; Lee, S.; Kim, D.Y.; Kim, J.G. Degradation characteristics of waste lubricants under different nutrient conditions. J. Hazard. Mater. 2007, 143, 65-72. [CrossRef]

68. Lee, S.H.; Oh, B.I.; Kim, J.G. Effect of various amendments on heavy mineral oil bioremediation and soil microbial activity. Bioresource. Technol. 2008, 99, 2578-2587. [CrossRef] 
69. Trasar-Cepeda, C.; Leirós, M.C.; Seoane, S.; Gil-Sotres, F. Limitations of soil enzymes as indicators of soil pollutions. Soil Biol. Biochem. 2000, 32, 1867-1875. [CrossRef]

70. Ramadassa, K.; Megharaj, M.; Venkateswarlu, K.; Naidu, R. Ecotoxicity of measured concentrations of soil-applied diesel: Effects on earthworm survival, dehydrogenase, urease and nitrification activities. Appl. Soil Ecol. 2017, 119, 1-7. [CrossRef]

71. Vidonish, J.E.; Zygourakis, K.; Masiello, C.A.; Sabadell, G.; Alvarez, P.J.J. Thermal treatment of hydrocarbon-impacted soils: A review of technology innovation for sustainable remediation. Engineering 2016, 2, 426-437. [CrossRef]

72. Mataix-Solera, J.; Guerrero, C.; García-Orenes, F.; Barcenas-Moreno, G.; Pilar Torres, M. Forest fire effects on soil microbiology. In Fire Effects on Soils and Restoration Strategies; Cerda, A., Robichaud, P.R., Eds.; Science Publishers: Enfield, NH, USA, 2009; pp. 133-175.

73. Cébron, A.; Cortet, J.; Criquet, S.; Biaz, A.; Calvert, V.; Caupert, C.; Pernin, C.; Leyval, C. Biological functioning of PAH-polluted and thermal desorption-treated soils assessed by fauna and microbial bioindicators. Res. Microbiol. 2011, 162, 896-907. [CrossRef] [PubMed]

74. Ren, J.; Song, X.; Ding, D. Sustainable remediation of disel-contaminated soil by low temperature thermal treatment: Improved energy efficiency and soil reusability. Chemosphere 2020, 241, 124952. [CrossRef] [PubMed]

(C) 2020 by the authors. Licensee MDPI, Basel, Switzerland. This article is an open access article distributed under the terms and conditions of the Creative Commons Attribution (CC BY) license (http://creativecommons.org/licenses/by/4.0/). 